\title{
Pathway Ordered
}

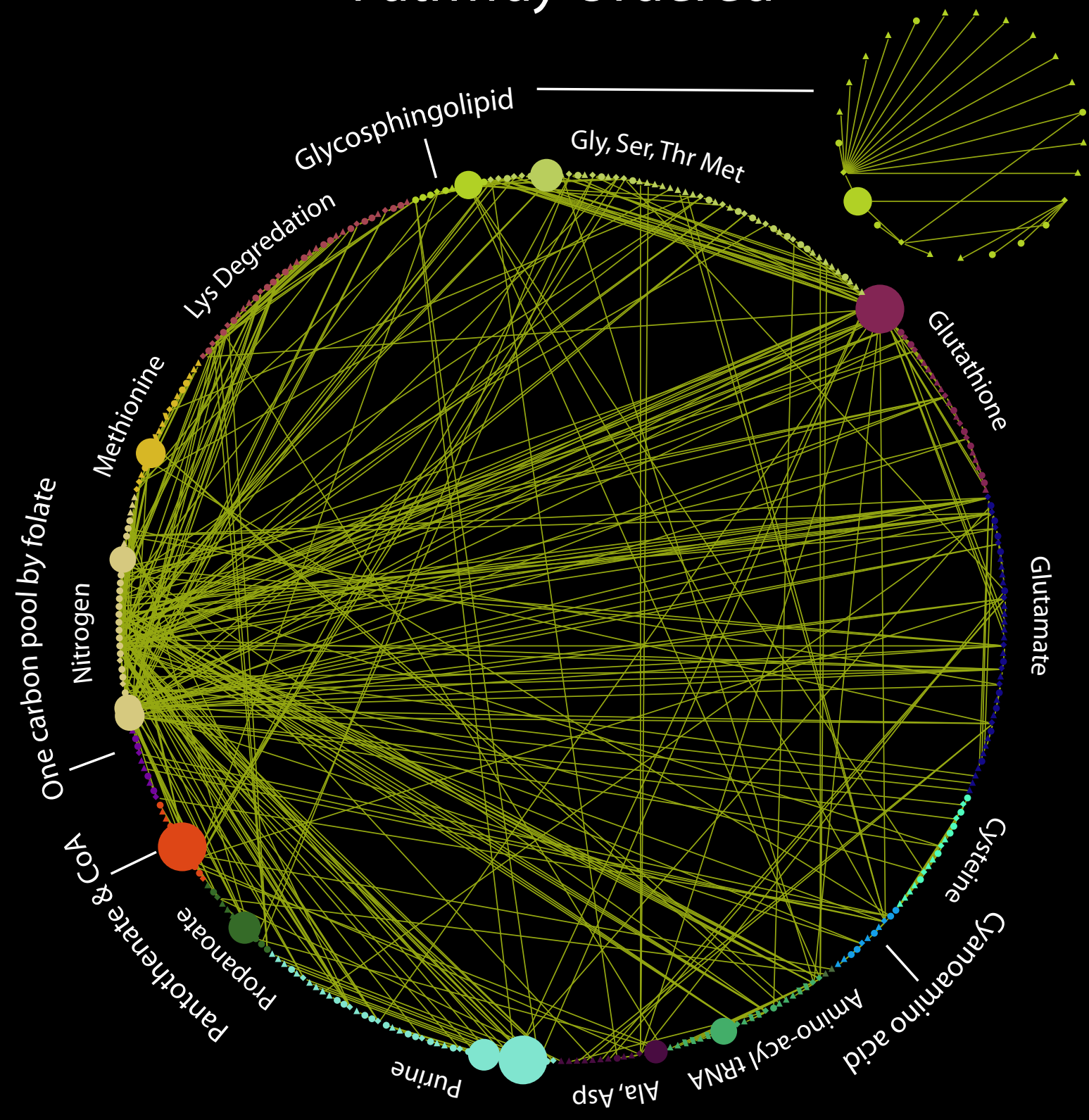

Weljie et al. Supp. Figure 1 